FACTA UNIVERSITATIS

Series: Law and Politics Vol. 18, N³, 2020, pp. 175-183

https://doi.org/10.22190/FULP2003175M

Review Paper

\title{
THE EUROPEAN APPROACH TO REGULATING DISINFORMATION
}

\author{
UDC 316.774:323.266(4-672EU) \\ 316.774:004.738.5(4-672EU)
}

\section{Anka Mihajlov Prokopović, Marija Vujović}

Faculty of Philosophy, University of Niš, Serbia

\begin{abstract}
This paper will present and analyze the European approach in combating disinformation, which has posed a major threat to democratic processes particularly after Brexit and the 2016 US presidential election. Social networks have emerged as a key factor that has allowed disinformation to spread at an unprecedented rate, damaging and polarizing the public sphere. Poorly informed citizens have less and less trust in the media and large political parties, and a society of post-truth is emerging as the post-modernist narrative has abolished great stories and brought cultural relativism (Cosentino, 2020). In these conditions, the European Union resorted to counteracting disinformation by focusing on large technology companies, the founders of social networks, and offering them a self-regulatory document, the Code of Practice on Disinformation (2018), two years after the US elections and Brexit, and a year before the European elections. The first encouraging results are noticed and announced in the reports submitted every month by the companies that signed the Code (Facebook, Google, Twitter, Mozilla, Microsoft, TikTok, and representatives of the advertising industry).
\end{abstract}

Key words: disinformation, EU media policy, Code of Practice on Disinformation, social networks

\section{INTRODUCTION}

The post-truth age, as a period in the contemporary society when truth is becoming less and less important, deals with the phenomenon of fake news. Fake news has become a characteristic of modern media and political sphere, especially after the US election in 2016 and Brexit in the same year. Although fake news existed before as well (Brigs, Berk, 2006: 295-297; Kelner, 2004: 328-378; Martinoli, 2017: 4-5), nowadays, thanks to the Internet

Received November $2^{\text {nd }} 2020 /$ Accepted November $20^{\text {th }} 2020$

Corresponding author: Anka Mihajlov Prokopović, PhD, Assistant Professor, Communicology and Journalism Department, Faculty of Philosophy, University of Niš, Ćirila i Metodija 2, 18000 Niš, Serbia.

E-mail: anka.mihajlov.prokopovic@filfak.ni.ac.rs

Marija Vujović, PhD, Assistant Professor, Communicology and Journalism Department, , Faculty of Philosophy, University of Niš, Ćirila i Metodija 2, 18000 Niš, Serbia. E-mail: marija.vujovic@ filfak.ni.ac.rs 
and social media, fake news is spreading rapidly, reaching a large number of people in a short period of time. This is not the only consequence of the digital environment. The digital media context has influenced journalism and the media in many ways. It has led to a change in journalistic practices, the emergence of new journalism genres (Mihajlov Prokopović, 2018) and the massive participation of audiences in the creation of media content (Hermida, 2011). In journalism, the influence of social media has been manifested through the growth of transparency, authenticity and cooperation between users and journalists (Bossio, 2017: 23-45).Generally speaking, the role of the media is changing. The media are no longer the only "gatekeepers", i.e. institutions that make decisions about what will be published in accordance with professional standards and editorial policy; nowadays, this role is shared with "people formerly known as the audience", as well as with other organizations and institutions. Digital technology and social media have made news publishing a fairly simple job: anybody with an Internet connection can publish the information they want; the online nature of the Internet facilitate the instant spread of information which has an immediate impact and meaning. The increase in the number of nonprofessional individuals who publish and spread news in the digital environment without adhering to the professional norms and ethics of journalism has had many consequences for democracy and the public sphere. The digital public sphere has enabled two types of effects: the positive one (such as the Arab Spring), which has enabled democratic change (Kastels, 2018: 91-105), and the negative one, embodied in strengthening authoritarianism thanks to using digital opportunities for such purposes and launching fake news (Pavlović, 2017: 54).

Online political debates, involving the executive authorities and ruling political parties, often produce negative consequences: "Instead of censoring the web debate, the authorities now engage in political debate on the Internet, spread false information, accuse the opponents of acting as foreign mercenaries who disrupt order or threaten the stability of the state, and prevent constructive web discussion from happening by making it absurd and meaningless“" (Morozov, 2011: 88, cited in Pavlović, 2017:55).

\section{SOCIAL MEDIA AND DISINFORMATION}

The report called "The Global Disinformation Order 2019: Global Inventory of Organised Social Media Manipulation" documents the rise of fake news globally as well as the role of computational propaganda in this rise. This research states: "Computational propaganda - the use of algorithms, automation, and big data to shape public life - is becoming a pervasive and ubiquitous part of everyday life" (Bradshaw, Howard, 2019: i). The report results state that there were organized social media manipulation campaigns in 70 countries in 2019, compared to 48 countries in 2018 and 28 countries in 2017 (Bradshaw, Howard, 2019: 2). The subjects of computational propaganda are governments, political parties and other organized groups. The most important findings of this research show that this type of propaganda has been used in as many as 26 countries for extremely undemocratic goals: to endanger human rights, to discredit political opponents, and to eliminate different opinions. Earlier studies also showed the rise of computational propaganda: "In 2017, Freedom House found that at least 30 governments around the world were employing troll farms to spread propaganda and attack critics" (Titcomb, 2017, cited in Cooper, Thomas, 2019:133). This Freedom House report states that fake news was an instrument that influenced political elections in 18 countries (Cooper, Thomas, 2019: 133). 
The research called "The Global Disinformation Order 2019: Global Inventory of Organised Social Media Manipulation" also reports that computational propaganda is widespread: $87 \%$ of surveyed countries used human accounts to spread fake content, $80 \%$ of countries used bot accounts, and $7 \%$ of countries used hacked accounts. Given that tech companies, owners of social media, remove fake accounts linked to computational propaganda, some countries hire people to use their own accounts and not fake accounts to spread propaganda and pro-government content (Bradshaw, Howard, 2019: 11).

Bradshaw and Howard indicate that Facebook is currently the social media platform that is used most for computational propaganda- in 56 countries (Bradshaw, Howard, 2019:i).In the forthcoming period, Facebook will try to use certain strategies to overcome this bad reputation that has been following this social network since the affair with the sale of data of Facebook users to Cambridge analytics (Mihajlov Prokopović, Vujović, 2019: 318). One of them is to form partnerships with organizations that check data authenticity (fact checkers) and take certain actions. For example, when a joint action establishes that certain content is fake, Facebook will rank such content lower in the News Feed in order to reduce the chances of sharing it further. If a webpage spreads fake news more than once, Facebook will cancel its advertising possibility and warn users that the post is fake. Web pages and domains that repeatedly share false news also see their distribution reduced and their ability to monetize and advertise removed. Thus, when a post is marked as fake, Facebook will warn people who see it or try to share it that the post is marked as fake. In Serbia, in July 2020, Facebook launched a fact-checking program in collaboration with Istinomer (The Truth-O-Meter) ${ }^{l}$ and AFP news agency. The same program has been launched in Croatia, Bosnia and Herzegovina, Montenegro and Northern Macedonia (PC Press, 30.7. 2020).Furthermore, the newly-formed Facebook Oversight Board for Content Decisions includes reputable and expert individuals ${ }^{2}$ whose task will be to make decisions on controversial content (Nova ekonomija, 8.5.2020). YouTube has recently announced that it will remove all videos containing misinformation about the Covid-19 vaccine. This platform has previously deleted around 200,000 videos in which misinformation about the Covid-19 virus was published (N1info, 2020). As many stakeholders in the digital media world are aware of the negative effects of fake news, the launch of the new social media called Telepath has been announced; it is claimed that it will prevent the spread of fake news(PC Press, 13. 10. 2020).

Computational propaganda is one of the ways to spread and give prominence to fake news. Moreover, the amount of fake news can be increased as a result of a lack of professional journalistic reporting, for example, due to the use of sources of information that are insufficiently verified, or not verified at all. An example of such practices in Serbia is the spread of fake news in 2011 that the Serbian novelist Dobrica Ćosić won the Nobel Prize in Literature, which was taken over from the fake Nobel Foundation's web site by

\footnotetext{
1 "Istinomer [The Truth-O-Meter] is a portal that checks facts by assessing public officials and politicians' statements and analysing all important social and economic issues. Statements are evaluated against the criteria of truthfulness, consistency and fulfillment of promises" (Istinomer, 2020).

${ }^{2}$ Nova ekonomija [New Economy]states: "The first 20 members of the Board will include a former prime minister, a Nobel Peace Prize laureate, and several constitutional law experts and human rights advocates...The Board is chaired by a former Judge on the United States Court of Appeals, a religious freedom expert Michael McConnell, a constitutional law expert Jamal Green, Colombian attorney Catalina Botero Marino, and a former Danish Prime Minister Hella Thorning Schmidt. The prominent members are a former judge of the European Court of Human Rights András Sajó, a Yemeni activist and aNobel Prize laureate Tawakkol Karman, a former editor-in-chief of the Guardian Alan Rusbridger, and aPakistani digital rights lawyer Nighat Dad (Nova ekonomija, 8.5.2020).
} 
some Serbian mainstream media and media outlets in the region (Danas, 6.10.2011). Moreover, fake news emerges as a result of citizen journalism. For example, in 2009, citizen journalists published false news on the CNN iReport (CNN website for user generated content) that Apple owner Steve Jobs suffered a heart attack, which caused a rapid falloff the company stock prices (NIN, 23.10.2008).Finally, fake news is being launched as a result of a new approach to online journalism where speed is becoming more important than checking. The difference between journalistic reporting and mistakes and disinformation should be emphasized here. Disinformation entails intentional dissemination of misleading information that is spread deliberately to deceive, while the above-mentioned examples of media and journalistic actions represent unintentional spreading of incorrect or partially correct information.

Bradshaw and Howard noted: "Social media, which was once heralded as a force for freedom and democracy, has come under increasing scrutiny for its role in amplifying disinformation, inciting violence, and lowering levels of trust in media and democratic institutions" (Bradshaw, Howard, 2019:21). Commissioned by the European Parliament, the study called "Disinformation and Propaganda - impact on the functioning of the rule of law in the EU and its Member States" assesses the impact of disinformation and strategic political propaganda disseminated through online social media sites. The study shows the events and topics that have been disrupted by disinformation spread via social media (European Parliament, 2019: 180-187). Nine social media were listed: Facebook, YouTube, WhatsApp, Instagram, Tumblr, Twitter, Reddit, Snapchat and 4Chan. Facebook has been involved in spreading disinformation at important political events. During the 2016 U.S. presidential election, Facebook was a platform used by many known and unknown people to spread disinformation about U.S. presidential candidates, especially in those states where candidates had a similar number of votes as predicted. Trump's campaign used dark posts on Facebook that were shown only to specific users. Disinformation was also related to general topics such as weapons, immigration and racial issues. Political events in Europe were also the subject matter of disinformation campaigns conducted via Facebook: the 2018 referendum on lifting the constitutional ban on abortion in Ireland, the 2017 election in France, the 2016 referendum on leaving the EU in Great Britain, and the 2017 election in Germany (European Parliament, 2019: 180-181).

EU countries react differently to these issues. Some European countries have reacted by passing laws on fake news (Germany, France and Italy). Poland has resorted to regulating political advertising, Portugal has instituted strict control over the political campaign funding and Sweden resorted to the development of media literacy (European Parliament, 2019: 10).

The European approach to disinformation is reflected in efforts to regulate this field. For the time being, the focus is on self-regulation. One reason for this is the fear of the European Union that too strict regulations might violate the basic democratic principles: "The analysis finds that the legal restriction of content may pose a greater harm to democracy than disinformation itself" (European Parliament, 2019: 10).

\section{EUROPEAN DISINFORMATION POLICY}

The European Union has formerly reacted to the dangers posed or aggravated by the new digital environment, such as hate speech online (Kostić, Vilić, 2016: 34) and the misuse of personal data (by adopting the General Data Protection Regulation - GDPR, 2016). 
The European Union disinformation policy has clearly defined this phenomenon and emphasized that the term "disinformation" will be used, rather than the term "fake news". Although these terms have partially similar content, there are also obvious differences. The term " disinformation" was defined in the European Commission document called "Tackling online disinformation: a European Approach, Communication from the Commission to the European Parliament, the Council, the European Economic and Social Committee and the Committee of the Regions" (EC Communication, 2018c). Disinformation includes "verifiably false or misleading information that is created, presented and disseminated for economic gain or to intentionally deceive the public, and may cause public harm. Public harm comprises threats to democratic political and policymaking processes as well as public goods such as the protection of EU citizens' health, the environment or security. Disinformation does not include reporting errors, satire and parody, or clearly identified partisan news and commentary" (EC Communication, 2018c: 3-4). Although the European response to the rise of disinformation has been largely driven by disruption of the democratic political process, Europe clearly recognizes the detrimental impact of disinformation in other areas as well, such as health, the environmental protection, and security.

Disruption of democratic political processes and distortion of the public sphere, which were caused by disinformation in some countries and rapidly spread to social media, were an alarm that prompted the European Commission to take action in this field. The first actions were taken in 2018 but, given that the European media policy envisages caution in order not to undermine the freedom of speech, it is still an emerging policy that would use soft instruments (Nenadić, 2019; Đukić, 2019).

In April 2018, the European Commission adopted the document called Tackling online disinformation: a European Approach Communication from the Commission to the European Parliament, the Council, the European Economic and Social Committee and the Committee of the Regions(EC Communication, 2018c). As noted by Nenadić, "this is the central document that sets the tone for future actions in this field" (Nenadić, 2019: 9). While that document was being created, a public debate on the EU policy towards disinformation was underway, involving the civil society, academics and the private internet and media sector. The High-Level Expert Group (HLEG) on Fake News and Online Disinformation was founded in early 2018, and it comprised from 39 members including: journalists, faculty professors, members of the civil society, and representatives of social media and internet platforms (Đukić, 2019: 29). Its task was to propose a legal framework for counteracting disinformation. For this purpose, the Commission used the conclusions of the public debate and the research results from the Eurobarometer Report on Fake News and Disinformation Online(EC Eurobarometer Report, 2018a). Some of the results of this research indicate that European Union citizens trust traditional media more than online media and social media. The majority of respondents from 28 EU member states believe that they can recognize fake news; they come across fake news once a week and most respondents believe that fake news is a threat to democracy (EC Eurobarometer Report, 2018a: 4). "Various institutions and media actors are seen as being responsible for stopping the spread of fake news. Respondents are most likely to think that journalists should act to stop the spread of fake news (45\%), followed by national authorities (39\%), press and broadcasting management (36\%), citizens themselves (32\%), online social networks (26\%), EU institutions (21\%), and non-governmental organisations (15\%)" (EC Eurobarometer Report, 2018:4).

The result of the efforts of this HLEG group is the report called A multi-dimensional approach to disinformation, Report of the independent High level Group on fake news and 
online disinformation(EC HLEG Report, 2018b), which proposed the involvement of the private sector in the consideration of new regulations. The report pointed out to the dangers posed by the rise of disinformation in the digital environment: "The risk of harm includes threats to democratic political processes, including integrity of elections, and to democratic values that shape public policies in a variety of sectors, such as health, science, finance and more" (EC HLEG Report, 2018b: 5). It also highlighted the five pillars which the European response to disinformation should rest on: transparency of online news; media and information literacy; empowering users and journalists; the diversity and sustainability of the European news media ecosystem; and research (EC HLEG Report, 2018b: 5-6). The HLEG proposed a self-regulatory approach that would encompass all important participants in the digital media sphere: "online platforms, news media organisations (press and broadcasters), journalists, fact-checkers, independent content creators, and the advertising industry" (EC HLEG Report, 2018b: 6). These stakeholders have been called upon to commit to the Code of Practice which should "reflect stakeholders' respective roles and responsibilities"(EC HLEG Report, 2018b: 6). According to Đukić, this approach has shown that "EU institutions continue to strive to achieve a balance between private and public interest, while protecting the sustainability and position of European media in the global market as well as the fundamental European democratic values - freedom of speech and thought, media pluralism, diversity and media freedom" (Đukić, 2019: 33).

The Code of Practice on Disinformation (EC Code of Practice, 2018d) was designed as a result of the recommendation by the HLEG. It was signed by the online platforms Facebook, Google, Twitter and Mozilla, as well as by representatives of the advertising industry in October 2018. The process of signing this document continued even after these initial signatures (Microsoft signed the Code in May 2019, and TikTok signed it in June 2020). Between January and May 2019, in the months leading up to the European Parliament elections, the European Commission specifically monitored the actions in this field through reports submitted by three powerful tech companies that signed the Code - Facebook, Google and Twitter. During this period, these three companies (the founders of Internet platforms) submitted monthly reports on the obligations they had undertaken as signatories to the Code of Practice on Disinformation. Moreover, the European Commission published the first annual report - a self-assessment of the signatories to this Code of practice. This document states that the situation in the field of combating disinformation is better than before the adoption of the Code and notes that the signatories made significant efforts to fulfill their commitments. Some of the commitments, such as actions to empower users and the research community, have been implemented incompletely and sporadically because these three online platforms (Facebook, Google and Twitter) were engaged in meeting European Parliament election commitments, for example, regarding the transparency of political advertising (EC Self-assessment Reports, 2019).

The European Digital Media Observatory (EDMO) was launched on 1 June 2020as part of the European approach to combat disinformation. The EDMO will bring together researchers and fact-checking organizations with the aim of improving anti-disinformation efforts. Its main activities will include: "mapping of fact-checking organisations in Europe; mapping, supporting and coordinating of research activities on disinformation; building a public portal for raising awareness, building resilience to online disinformation and supporting media literacy campaigns; designing framework to ensure secure and privacyprotected access to platforms' data for academic researchers; and providing support to public authorities in monitoring the policies to limit the spread and the impact of disinformation"(EC EDMO, 2020). 


\section{CONCLUSION}

Disruption and endangerment of the online information process caused by disinformation placed and rapidly distributed through social media and platforms are integral parts of the post-truth society. It is one of the key phenomena that characterizes the political and cultural sphere of this social structure. In addition to spreading misinformation, a post-truth society emphasizes the existence of polarized and emotional public opinion, political communication strategically linked to computer propaganda and political marketing that relies on a cognitive-behavioral approach (Cosentino, 2020: 3-4).

The abundance of disinformation, disoriented or poorly informed citizens, political tensions and serious violations of democracy are the consequences of such a structure. It was clearly shown by Brexit, the 2016 presidential elections in America, the elections in Brazil, the elections in India, Indonesia and Thailand (Nenadić, 2019: 2). The power of technology companies (founders of social media) rises, including (among other things) the engagement of users in dissemination of content (either true or false) (Cosentino, 2020: 2). This makes the problem of "disinformation abundance" very serious and raises doubts about the determination of these technological giants to regulate themselves.

The European approach to counteracting disinformation started with the idea to force technology companies to adhere to the rules of good practice by limiting the circulation of content that is false or harmful. The Code of Practice on Disinformation was adopted in 2018, as the first self-regulatory document for online platforms in the world. After signing this document, Facebook, Google, Twitter and other signatories are expected to fulfill by the undertaken commitments and take concrete action. Further measures in this area will depend on the European Commission's evaluation of the obtained results. This approach is based on the principles of transparency, promoting quality journalism, mobilizing the private sector, raising awareness and empowering the research community (Nenadić, 2019: 13-14).

In the circumstances of the ongoing Covid-19 pandemic, it is particularly important to note that this approach has facilitated the fight against disinformation in the European communication area not only in the field of political communication but also in other public areas; for example, in the field of health policies has strengthened action against disinformation with the aim of preserving and protecting the public interest in this area(European Commission, 10.07.2020).

\section{REFERENCES}

Bossio, D., (2017). Journalism and Social Media, Palgrave Macmillan, Cham.

Bradshaw, S., Howard, P., (2019).The Global Disinformation Order 2019 Global Inventory of Organised Social Media Manipulation, The Computational Propaganda Project at the Oxford Internet Institute, University of Oxford.

Brigs, A., Berk, P., (2006). Društvena istorija medija [Social History of the Media], Clio, Beograd.

Cooper, T., Thomas, J.,(2019). Nature or Nurture: A Crisis of Trust and Reason in the Digital Age, Albany, London.

Cosentino, G., (2020). Social Media and the Post-Truth World Order: The Global Dynamics of Disinformation, Palgrave Macmillan, Springer Nature Switzerland AG, Cham, Switzerland.

Đukić, M., (2019). Odgovor Europske unije na problem lažnih vijesti - regulativni okvir u nastanku, [European Union Response to the Problem of Fake News - Regulatory Framework in the making], In: Hrnjić Kuduzović, Z., Kulić, M., Jurišić, J., (eds), Vjerodostojnost medija: Doba lažnih informacija, Zbornik radova sa devete regionalne naučne konferencije Vjerodostojnost medija, Filozofski fakultet Univerziteta u Tuzli, BiH, pp. 19-38.

Hermida, A., (2011). Mechanism of Participations: How audience options shape the conversation, In: Singer, J. B. et al. (ed.), Participatory Journalism: Guarding Open Gates at Online Newspapers, Boston, Wiley-Blackwell, pp. 13-33. 
Kastels, M., (2018). Mreže revolta i nade [Networks of Outrage and Hope], Službeni glasnik, Beograd.

Kelner, D., (2004). Medijska kultura [Media Culture], Clio, Beograd.

Kostić, M., Vilić, V., (2016). Hate speech on the Internet, In: Facta Universitatis Series: Law and Politics, Vol. 14, No 1,2016, pp. $31-40$

Martinoli, A., (2017). Fake news - medijska produkcija i kriza novinarstva u doba post istine [Fake news - media production and the crisis of journalism in the post-truth age], In: Zbornik Fakulteta dramskih umetnosti, 32, pp. $43-60$

Mihajlov Prokopović, A., (2018). Internet social networks and traditional media, In: Теме: часопис за друштвене науке, Vol.XLII, No 4, pp. 1081-1105

Mihajlov Prokopović, A., Vujović, M., (2019). Media in the Digital Age: Regulatory Aspects, In: Zbornik radova Pravnog fakulteta u Nišsu, LVIII (85), pp. 315-330.

Nenadić, I., (2019). Unpacking the "European approach" to tackling challenges of disinformation and political manipulation, In: Internet Policy Review, Vol. 8, Issue 4, pp.1-22.

Pavlović, J., (2017). Digitalizacija javne sfere u Srbiji: online pritisci izvršne vlasti na ombudsmana i reakcija opoziciono opredeljene Tviter zajednice [Digitalization of the public sphere in Serbia: Online executive power pressure on the Ombudsman and the reaction of the oppositional Twitter community], In: Politicke perspektive, vol. 7, No.3, pp. $51-75$

\section{ONLINE SOURCES}

European Commission/EC Eurobarometer (2018a):Flash Eurobarometer 464: Report on Fake News and Disinformation Online(Feb.2018), available at https://op.europa.eu/en/publication-detail/-/publication/2d79b85a-4cea-11e8-be1d01aa75ed71a1/language-en, accessed on 21 Oct.2020.

European Commission/EC HLEG Report (2018b). A multi-dimensional approach to disinformation. Report of the independent High level Group (HLEG) on fake news and online disinformation (12 March 2018), https://ec.europa.eu/digital-single-market/en/news/final-report-high-level-expert-group-fake-news-andonline-disinformation, accessed on 20 October 2020.

European Commission/EC Communication (2018c). Communication COM/2018/236 Tackling online disinformation: a European Approach, Communication from the Commission to the European Parliament, the Council, the European Economic and Social Committee and the Committee of the Regions, Brussels, 26 April 2018, https://eurlex.europa.eu/legal-content/EN/TXT/?uri=CELEX:52018DC0236, accessed on 22 October 2020.

European Commission/EC Code of Practice (2018d): Code of Practice on Disinformation, 26 September 2018, https://ec.europa.eu/digital-single-market/en/news/code-practice-disinformation,accessed on 20 October 2020

European Commission/EC Self-assessment Reports (2019): Annual self-assessment reports of signatories to the Code of Practice on Disinformation 2019, accessed on 22 October 2020, https://ec.europa.eu/digital-single-market/en/ news/annual-self-assessment-reports-signatories-code-practice-disinformation-2019.

European Commission/EC (10.06.2020): Coronavirus: EU strengthens action to tackle disinformation, https://ec.europa.eu/commission/presscorner/detail/en/ip_20_1006, accessed on 22 Oct. 2020,

European Commission/EC (7.07. 2020). European Digital Media Observatory, accessed on 22 Oct. 2020, https://ec.europa.eu/digital-single-market/en/european-digital-media-observatory.

European Parliament/EP (2019). Disinformation and propaganda-impact on the functioning of the rule of law in the EU and its Member States, accessed on 18 October 2020,https://www.europarl.europa.eu/RegData/etudes/ STUD/2019/608864/IPOL_STU(2019)608864_EN.pdf.

Istinomer.rs (2019): Sta je Istinomer? [What is the Truth-O-Meter?], accessed on 20 October 2020, https://www.istinomer.rs/o-istinomeru/.

Danas (6.10.2011): Bačić, B., Milikić, M., Ćosić bio nobelovac sat vremena [Ćosić was a Nobel laureate for an hour], Danas, 6 October 2011, accessed on 21 October 2020, https://www.danas.rs/drustvo/cosic-bio-nobelovacsat-vremena/

NIN (23.10.2008): Nikšić, S., Demokratizacija medijske laži [Democratization of media lies], NIN, br.3017, 23.10.2008:http://www.nin.co.rs/pages/article.php?id=40847, accessed 20 Oct. 2020.

N1info.com (14.10.2020): Jutjub briše sve objave sa dezinformacijama o vakcini protiv Kovida [YouTube will remove all posts containing misinformation about the Covid-19 vaccine], N1 Zagreb, 14 October 2020, http://rs.nlinfo.com/SciTech/a660814/Youtube-brise-objave-u-kojima-se-iznose-dezinformacije-o-vakcini-protivkovida.html,accessed on 20 October 2020.

Nova ekonomija (8.5.2020). Fejsbuk osniva poseban nadzorni odbor za sadržaj [Facebook to Form the Oversight Board for Content Decisions], Nova ekonomija, 8 May 2020, https://novaekonomija.rs/vesti-iz-sveta/fejsbuk-osnivaposeban-nadzorni-odbor-za-sadr\%C5\%BEaj, accessed on 19 October 2020. 
PC Press (30.7. 2020): Facebook pokrenuo nezavisni program za proveru informacija u Srbiji [Facebook launched a fact-checking program in Serbia], PC Press, 30 July 2020, https://pcpress.rs/facebook-pokrenuo-nezavisni-programza-proveru-informacija-u-srbiji/,accessedon 19 October 2020.

PC Press (13. 10. 2020): Barašević, T. Nova društvena mreža - Telepath [Telepath -a new Social Network], PC Press, 13 October 2020, https://pcpress.rs/nova-drustvena-mreza-telepath/, accessedon19 October 2020.

\section{EVROPSKI PRISTUP REGULACIJI DEZINFORMACIJA}

Ovaj rad predstaviće i analizirati evropski pristup u borbi protiv dezinformacija koje su se nametnule kao velika pretnja demokratskim procesima, što je posebno postalo očigledno posle Bregzita i američkih predsedničkih izbora 2016. godine. Društvene mrě̌e pojavile su se kao ključni faktor koji je omogućio da se dezinformacije šire neslućenom brzinom nanoseći štetu javnoj sferi i polarizujući je. Loše informisani građani sve manje veruju medijima i velikim političkim partijama, a društvo post-istine nastaje pošto je post-modernistički narativ ukinuo velike priče $i$ doneo kulturni relativizam (Cosentino, 2020). Evropska unija u tim uslovima pribegava borbi protiv dezinformacija stavljajući u njen centar velike tehnološke kompanije osnivače društvenih mreža nudeći im samoregulatorni dokument „Kodeks prakse u suzbijanju dezinformacija" (2018) dve godine posle američkih izbora i Bregzita, a godinu dana pre evropskih izbora.Prvi pozitivni rezultati uočavaju se $i$ saopštavaju u izveštajima koje svakog meseca podnose kompanije potpisnice Kodeksa (Facebook, Google, Twitter, Mozilla,Microsoft, TikTok i predstavnici oglašivačke industrije).

Ključne reči: dezinformacije, evropska medijska politika, Kodeks prakse u suzbijanju dezinformacija, društvene mreže 